\title{
7: $101521887-101555613$
}

National Cancer Institute

\section{Source}

National Cancer Institute. 1: 101521887-101555613. NCI Thesaurus. Code C41708.

Physical location of APS_Gene 